\title{
Crisis in the Courtroom
}

\section{The Discursive Conditions of Possibility for Ruptures in Legal Discourse $^{*}$}

Laura M. Henderson

\section{Introduction}

Contemporary approaches to terrorism are characterized by a turn to a logic of precaution. ${ }^{1}$ Political actors speak in terms of risk, and political action has become structured by a desire to avoid this risk at any cost. ${ }^{2}$ Yet, this is not just a characteristic of political language. This precautionary turn can be seen within legal discourse as well and the judiciary has proven itself intimately involved with this discourse of precaution, using the same logic of prevention that guides political action against terrorism. ${ }^{3}$ However, while the judiciary's precautionary approach to terrorism has been evaluated and critiqued for what it means for the rule of law, explanations of how this precautionary shift in legal discourse was able to come about are missing from the literature. This article aims to fill this gap by exploring the discursive conditions of possibility that gave rise to this shift. I focus on the conditions of possibility that allowed for the break with the previously-dominant approach to terrorism, as well as on the crisis discourse that provided discursive justification for the new preventative approach. I argue that the executive and judiciary's use of this crisis discourse (the discursive construction of an existential threat that necessitates a structural change) is what made the precautionary turn possible.

While the events that precipitated this shift occurred more than a decade-and-ahalf ago, the insight this article offers into crisis discourse is relevant today. The prevalence of crises - and crisis discourses - in the modern risk society has certainly not diminished since 2001, as the global financial crisis ${ }^{4}$ and the refugee crisis have shown. By returning to a number of well-known terrorism cases, I call

* The author would like to thank Prof. Bart van Klink, Prof. Wouter Veraart, Prof. Marc de Wilde, Prof. Wouter Werner, Prof. Beatrice de Graaf, and Dr. Tanja Aalberts. All errors are mine.

1 Rens van Munster describes this shift as 'a move from defense to prevention,' see 'The War on Terrorism: When the Exception Becomes the Rule,' International Journal for the Semiotics of Law 17, no. 2 (2004): 142. See further Marieke de Goede, 'The Politics of Preemption and the War on Terror in Europe,' European Journal of International Relations 14, no. 1 (2008): 163-65 and Filip Gelev, 'Checks and Balances of Risk Management: Precautionary Logic and the Judiciary,' Review of International Studies 37 (2011): 2237-52.

2 De Goede, 'Politics of Preemption,' 164.

3 Marieke de Goede and Beatrice de Graaf, 'Sentencing Risk: Temporality and Precaution in Terrorism Trials,' International Political Sociology 7, no. 3 (2013): 328.

4 Alon Lischinsky, 'In Times of Crisis: A Corpus Approach to the Construction of the Global Financial Crisis in Annual Reports,' Critical Discourse Studies 8, no. 3 (2011): 153-68. 
on the reader to look again at these cases and to look for the discursive mechanisms of crisis. This analysis also provides a new way of viewing shifts in legal discourse in general. No longer does the discussion merely focus on whether such a shift like the precautionary turn was a threat to the rule of law or, alternatively, a rational response to the threat of terrorism. Instead, shifts in legal discourse can be seen as the result of struggle and contest, a process that can be actively interfered with and engaged in once one is aware of the discursive parameters. Such a perspective empowers - and perhaps requires - those who come into contact with this discourse to decide how they wish to participate in this struggle.

In order to address the issues set out above, the article will proceed as follows. In section 2, I discuss the precautionary turn in the judiciary's legal discourse. Drawing on studies of the judiciary in North America, Western Europe, and Australia, this section will show that the shift toward precautionary logic was not just a political shift, but one that took place in legal discourse as well. ${ }^{5}$ Further, this section will show that although the studies conducted on precautionary discourse in the legal realm are convincing, they lack sufficient exploration of how this shift was able to come about. In section 3 I address this lacuna, focusing on how the conditions for possibility for this shift came about. I introduce Laclau and Mouffe's notion of dislocation, a concept that has been under-theorized and under-operationalized. ${ }^{6}$ I argue that the events of 9/11 were unable to be incorporated in the existing discursive structure at the time, leading to a discursive void' after $9 / 11 .{ }^{7}$ Next, in section 4 , I explore how this void was filled by a new discourse, the discourse of crisis. This crisis discourse engaged in a 'double articulation.' First, it called into being a rupture with the past and, subsequently, it articulated a 'new era' that was characterized by preventive action against terrorism. This crisis discourse framed the events of $9 / 11$ in such a way that preventive action became the only seemingly-logical solution to the constructed problem of international terrorism. Importantly, I show not only that this discourse was adopted by the executive in its public speeches, but also by the judiciary in the courtroom (section 5). Here, I argue that another look at a number of the key cases exhibiting precautionary logic in legal discourse can reveal how crisis discourse was used by the judiciary in a way that made the shift toward precautionary logic possible. In this way, it can be said that crisis discourse provided the necessary discursive conditions for the precautionary turn in legal discourse. Finally, section 6 concludes that an understanding of the mechanisms of crisis discourse is a necessary starting point for further research on the normative implications of this type of speech as well as for further theorization on the role of the judiciary in times of (discursive) crises.

5 This article characterizes discourse as 'legal' when a discourse is employed by actors dealing with questions of interpretation of legal norms and rules.

6 For a rare example of operationalization, see Chris Methmann, 'The Sky is the Limit: Global Warming as Global Governmentality,' European Journal of International Relations 19, no. 1 (2013): 69-91.

7 I borrow the term 'discursive void' from Jack Holland, see 'From September 11th, 2001 to 9-11: From Void to Crisis,' International Political Sociology 3, no. 3 (2009): 275-92. 


\section{The precautionary turn in legal discourse}

After September 11, 2001, the starting point for approaches to national security became 'prevention rather than defense against actual threat.' $\mathrm{A}$ 'discourse on eventualities' emerged in the U.S. that called for a 'permanent military policing through the mechanisms of prevention and pre-emption. ${ }^{9}$ Although it might be assumed that the judiciary would remain immune to such changes in political discourse, a number of studies on the role of the judiciary in reviewing counterterrorism measures indicate that this 'fundamental change' ${ }^{\text {'0 }}$ in approaches to terrorism also occurred in the legal discourse used by the judiciary. In the years since 9/11, an 'alternative, military-based approach [to terrorism], rooted in the language and logic of a global armed conflict against al Qaeda and associated terrorist organizations ${ }^{11}$ has become an institutionalized and normalized part of legal practice and legal discourse. This has been shown to be the case not only in the U.S., but broadly throughout courts in the West. Studies of judiciaries in the U.S., and also in Canada, Australia and the Netherlands, confirm this trend. ${ }^{12}$ "While courts have resisted some aspects of this new paradigm, they have not, for the most part, challenged its underlying premise that holding terrorism suspects outside the criminal justice system is a legitimate exercise of wartime power. ${ }^{13}$ Judicial review may give 'the appearance of scrutinizing acts of parliament or executive actions' but nevertheless upholds 'their validity using the logic of precaution. ${ }^{14}$ 'The judiciary adopts the logic of precaution in exactly the same way as the other two branches of government. ${ }^{15}$ Instead of acting as a counterweight toward the precautionary shift in politics and law, 'courts are central to the precautionary risk rationality of government. ${ }^{16}$ The previously dominant legal way of approach-

8 Van Munster, 'War on Terrorism,' 146.

9 Van Munster, 'War on Terrorism,' 142.

10 Van Munster, 'War on Terrorism,' 146.

11 Jonathan Hafetz, 'Military Detention in the "War on Terrorism": Normalizing the Exceptional after 9/11,' Columbia Law Review Sidebar 112 (2012): 31.

12 See Hafetz, 'Military Detention,' Gelev, 'Checks and Balances,' and De Goede and De Graaf, 'Sentencing Risk,' respectively.

13 Hafetz, 'Military Detention,' 37.

14 Gelev, 'Checks and Balances,' 2239.

15 Gelev, 'Checks and Balances,' 2241.

16 Gelev, 'Checks and Balances,' 2240. 
ing counterterrorism - namely by prosecuting acts already carried out ${ }^{17}$ - was replaced with a different, precautionary, approach. ${ }^{18}$

The new approach to counterterrorism affected many areas of legal discourse, including both administrative and criminal law. ${ }^{19}$ The effect of the precautionary turn is not only the increase in preventive administrative measures but also a change in criminal law itself, "in order to enable the prosecution of potential future terrorists. This has taken place most notably through the criminalization of ancillary offenses, such as facilitation, training, financing, or incitement. ${ }^{20}$ De Goede and De Graaf wish to impress upon their audience that these changes must not be viewed as enacting 'a space beyond the law.' Instead, they argue that 'through these changes, notions of risk and future threat are interpellated into legal practice, and behaviors increasingly removed from the act of violence are brought within the remit of criminal law. ${ }^{21}$ These authors conclude that the infusion of precautionary reasoning into the criminal law itself, leads to 'legalized' exceptional measures. ${ }^{22}$

Evidence of a precautionary turn in legal discourse after September 11, 2001 can be found in both administrative law and criminal law, both in the U.S. and in other Western judiciaries. Yet, no detailed explanation for how this precautionary turn was precipitated is offered. Each study dealt with above addresses this issue merely briefly. While Hafetz speaks of the "language and logic of a global armed conflict $^{23}$ playing a role in justifying this shift, he does not further explain what this role is. De Goede and De Graaf touch upon the interaction between law and politics, noting that the precautionary turn 'can be related to shifting notions of public and political responsibility' and processes and cycles of secondary risk management, ${ }^{24}$ but do not make clear what the connecting and mediating factor

17 Douglas Feith, 'The Global War on Terrorism,' Council on Foreign Relations, Washington DC, November 13, 2003, available at http://www.dougfeith.com/docs/2003_11_13_Feith_CFR_ Global_War_on_Terrorism.pdf, last accessed September 28, 2017.

18 The precautionary approach and the precautionary (legal) discourse that supported it are not unique to the post-9/11 context, although the approach and discourse discussed here are limited to that context. Precaution is intimately related to risk; the sooner a measure addresses a potential risk and the more strictly it limits the assumed cause of the risk, the more precautionary the measure is, see J.B. Wiener and M.D. Rogers, 'Comparing Precaution in the United States and Europe,' Journal of Risk Research 5, no. 4 (2002): 320. Moreover, precautionary discourses have been described as politicizing decisions about risk, see S. Bernstein, 'Liberal Environmentalism and Global Governance,' Global Environmental Politics, 2, no. 3 (2002): 12. In general, the precautionary approach can be described as a shift from assuming something is safe until it is demonstrated to be risky to assuming something is potentially dangerous until it is demonstrated safe, see Steve Maguire and Jaye Ellis, 'The Precautionary Principle and Risk Communication,' in Handbook of Risk and Crisis Communication, ed. Robert L. Heath and H. Dan O'Hair (Routledge: New York, 2009), 125.

19 Hafetz, 'Military Detention,' 42 and De Goede and De Graaf, 'Sentencing Risk,' 314.

20 De Goede and De Graaf, 'Sentencing Risk,' 315.

21 De Goede and De Graaf, 'Sentencing Risk,' 315.

22 De Goede and De Graaf, 'Sentencing Risk,' 315.

23 Hafetz, 'Military Detention,' 31.

24 De Goede and De Graaf, 'Sentencing Risk,' 327. 
is between these changing notions of risk management in the social realm and in legal discourse. Finally, Gelev attributes the judiciary's use of a logic of risk to the influence of the 'politics of fear' ${ }^{25}$ but fails to explicate how this influence is exacted. The remainder of this article seeks to further understand how the precautionary turn was made possible by using a theory of discursive dislocation and rupture and connecting this to a crisis discourse that emerged after September 11, 2001.

\section{Discursive dislocations}

In this section I argue that the precautionary turn in legal discourse can be best understood with the concepts of lack and discursive dislocation that Ernesto Laclau and Chantal Mouffe have pioneered. After a brief introduction into Laclau and Mouffe's general theory of social meaning, I will proceed to elaborate on these concepts. In the next section, I operationalize these concepts by linking them to the discursive experience after $9 / 11$ and in section 5 I discuss how previously dislocated discourses were finally ruptured by crisis discourse used in legal reasoning.

Laclau and Mouffe have developed a postfoundationalist theory of meaning that starts from the notion that social meaning is a product of discursive construction. While Laclau and Mouffe recognize a 'real' world outside of discursive construction, they contend that humans' ability to perceive that 'real' world is always mediated by discourse:

'The fact that every object is constituted as an object of discourse has nothing to do with whether there is a world external to thought ... An earthquake or the falling of a brick is an event that certainly exists, in the sense that it occurs here and now, independently of my will. But whether their specificity as objects is constructed in terms of "natural phenomena" or "expression of the wrath of God", depends upon the structuring of the discursive field. ${ }^{26}$

For Laclau and Mouffe, our conception of reality is created through discursive struggle. Because discourse is that which produces meaning, all identities, social practices and social meaning are radically contingent upon the particular power relations that go into supporting various discourses that manage to gain enough prominence and credibility to order social, religious, political and economic life. There is no 'inevitable' or 'essential' meaning of social reality and, importantly, discourse can only temporarily and partially describe reality. ${ }^{27}$ Often, this fundamental inability to capture the (nonexistent) essential meaning of social reality is

25 Gelev, 'Checks and Balances,' 2242.

26 Ernesto Laclau and Chantal Mouffe, Hegemony and Socialist Strategy: Towards a Radical Democratic Politics (New York: Verso, 1985 (2014)), 94.

27 See further Chris Methmann and Delf Rothe, 'Politics for the Day after Tomorrow: The Logic of Apocalypse in Global Climate Politics,' Security Dialogue 43, no. 4 (2012): 326. 
masked by discursive structures that purport to represent an essential meaning. Yet, at times, discursive structures no longer succeed in masking social contingency, revealing the inevitable incompleteness of discourse. It is these times, when contingency is made visible, that we speak of a dislocation. ${ }^{28}$ The temporary and partial nature of discourse is revealed through an experience of the 'failure of "structural conditions" to continue to interpellate subjects. ${ }^{29}$ The previously existing discourse that constituted social meanings and identities is revealed as incomplete. Thus, for example, when inflation and unemployment simultaneously occurred in the early 1970s, the then-hegemonic Keynesian discourse that proclaimed such 'stagflation' would never occur was unable to incorporate this event. The experience of that which was excluded from the realm of possibility led to a dislocation of the Keynesian orthodoxy. ${ }^{30}$

Within this view, it must be emphasized that it is not the dislocation itself that makes the previous discourse incomplete. Rather, this is attributed to the fact that discourses can never fully succeed in constituting social reality. There is always emptiness, or a lack, that remains unconstituted. It is this lack that becomes apparent again in dislocation; indeed it is this lack that makes dislocation possible. 'Dislocation is not just an empirical imperfection, but designates the impossibility of closure. ${ }^{31}$ Dislocations are, as it were, the result of this lack becoming visible. A lack can become visible when the 'constitutive outside' of a discourse disrupts the discursive structure. Here, the constitutive outside can be seen as that which was excluded as a necessary condition for forming the discourse, and when it reveals itself as present, it reveals the impossibility of the fullness of the now-dislocated discursive structure. This 'literally induces an identity crisis for the subject,' as the previously existing identities and social meanings are no longer possible. The dislocated discourse can no longer 'fulfill its function of interpellating subjects into stable, "normalized" forms of identification. ${ }^{\text {'32 At }}$ the same time, dislocations are 'the foundation on which new identities are constituted.' ${ }^{33}$ After the previous discourse is dislocated and the lack is made visible, one of two things can happen. Either the dislocated discourse is able to recover and reconstitute itself as a mask for the lack, or the dislocated discourse will not recover and will experience a definitive rupture, and will be replaced by an alternative discourse that succeeds in filling the void. This new discourse must successfully rearticulate social reality again in a fictitiously complete way, so as to mask the lack that is ever-present.

28 David Howarth and Yannis Stavrakakis, 'Introducing Discourse Theory and Political Analysis,' in Discourse Theory and Political Analysis: Identities, Hegemonies and Social Change, ed. David Howarth, Aletta J. Norval, and Yannis Stavrakakis (Manchester: Manchester University Press, 2000), 13.

29 Aletta Norval, Deconstructing Apartheid Discourse (London: Verso, 1996), 13, 26.

30 Jacob Torfing, New Theories of Discourse: Laclau, Mouffe and Zizek (Oxford: Blackwell, 1999), 240.

31 Urs Staheli, 'Competing Figures of the Limit: Dispersion, Transgression, Antagonism, and Indifference,' in Laclau: A Critical Reader, ed. Simon Critchley and Oliver Marchart (New York: Routledge, 2004), 238.

32 Norval, Deconstructing Apartheid Discourse, 27.

33 Ernesto Laclau, New Reflections on the Revolution of Our Time (New York: Verso, 1990), 39. 
Let us now attempt to operationalize the concepts of lack and dislocation by use of the discursive structures that were in play after 9/11. My argument will be developed as follows: Immediately after $9 / 11$, a dislocation occurred as the events of 9/11 revealed a lack. The attacks on U.S. territory were initially inexplicable. There were no words, no current discourse, to explain or understand these events. The attacks had shown that the previous discourses were unable to fully incorporate all of reality and the lack had become apparent. Evidence of this dislocation can be found in the initial silence from media and politicians as well as in interviews immediately after the attacks with U.S. residents. This dislocation created room for a new discourse and quickly, but not immediately, a discourse emerged that would end up once again covering the lack revealed by the events on 9/11. Section 4 will show this discourse was one of international terrorist threat and the need for prevention over prosecution of terrorist activity. Section 5 will show that these discursive elements were present in legal discourse as well and were the key justification for the precautionary turn therein.

\section{A lack revealed; a discourse dislocated}

Immediately after the events of 9/11, a feeling of confusion and disorientation prevailed, 'as language failed to adequately or consistently regulate the meaning of the unfolding events. ${ }^{34}$ The very first response of the Bush administration, on the evening of September 11th, was lacking the decisiveness and unity of later executive discourse and was "little more than "a doughy pudding of stale metaphors" lacking the moral clarity of subsequent speeches.' ${ }^{35}$ Individuals also showed an initial inability to attribute any meaning to these events. Based on interviews conducted directly after the events of $9 / 11$, Holland concludes that the events of that day were 'unable to be incorporated into existing discourses.'36 These are the symptoms of a lack (or void in Holland's terms) being revealed. Existing discourses failed to adequately explain or give meaning to the events of 9/11. ${ }^{37}$ As this lack was revealed, previous security discourses were dislocated, as they were unable to incorporate the events of $9 / 11$ within their structure of meaning. The discursive dislocation that $9 / 11$ precipitated, this 'void in meaning' that was revealed as previous security discourses became unable to provide social meaning, acted as a vacuum that needed to be filled. ${ }^{38}$

The way in which this vacuum would be filled was not inevitable. The filling of the gap in meaning was the result of a struggle between different discursive construc-

34 Holland, 'From September 11th, 2001 to 9-11,' 275-76.

35 David Frum, The Right Man: An Inside Account of the Surprise Presidency of George W. Bush (London: Weidenfeld and Nicolson, 2003), 127 as cited in Jack Holland and Lee Jarvis, "'Night Fell on a Different World”: Experiencing, Constructing and Remembering 9/11,' Critical Studies on Terrorism 7 , no. 2 (2014): 194.

36 Holland, 'From September 11th, 2001 to 9-11,' 278-79. Holland shows one respondent's difficulty in finding a way to describe his experience of 9/11: '[I]t made it difficult to talk ... speaking clearly wasn't really happening at that point, it was very difficult.' Another respondent echoed this sentiment: 'I felt nothing because I couldn't understand.'

37 Holland, 'From September 11th, 2001 to 9-11,' 276.

38 Holland, 'From September 11th, 2001 to 9-11,' 289. 
tions - and different agents employing these discourses - for acceptance by relevant audiences. "Initially unregulated by discourse, the "events" did not mean anything for certain. ${ }^{39}$ To put this in more concrete terms, this is to say that a different discursive response could have been launched, for example one in which a solution is sought within the pre-existing and largely unmodified structures of the state regime, generally in the absence of a crisis narrative. ${ }^{40}$ In such a case, the dislocated discourse would have been 'patched up' and repaired; modified and reformed, but not definitively ruptured. In that case, the new precautionary discourse would not have gained traction. But this is not what happened. Instead, as the following section will address, a crisis narrative emerged and was successfully deployed by actors within the executive and media, ${ }^{41}$ and - as we will see - the judiciary as well, and the previous discourse on terrorism and international security was not just dislocated but ruptured. The rupturing of the old discourse and the imposition of a new trajectory 'relied upon the success of the articulation of the events of 9-11 - as symptomatic of a wider crisis - and on the success of the articulation of the decisive intervention that deemed a War on Terror as urgent.' ' $92-11$ became a crisis through a process of discursive construction' 43 and in doing so, set the new policies of the War on Terror underway. ${ }^{44}$

\section{Crisis in a post-9/11 world}

This section attempts to shed light on the conditions that made the precautionary shift in legal discourse possible. First, this section introduces the idea of 'crisis discourse' as a particular type of discourse with a particular effect: the rupturing of already-dislocated discourses. In this section, I start from the assumption that in order to understand what made the shift in legal discourse possible, one must look beyond legal discourse to the general context of post-9/11 discourse.

As sketched above, the immediate response to the events of 9/11 was that of disbelief and an experience that language was not sufficient to describe or understand these happenings. Yet, this response, although immediate, was certainly not long-lived. In the days and weeks that followed September 11, 2001, a new discourse was pieced together that attributed meaning to the events of this day. Although the executive's initial response was reflective of the confusion and dislocation that occurred after the events of $9 / 11$, by the time of the President's address to Congress on September 20th, the executive's discourse had become 'clear and powerful.' 45 This new discourse is described here as a 'crisis discourse'

41 See generally Stuart Croft, Culture, Crisis and America's War on Terror (Cambridge: Cambridge University Press, 2006).

42 Holland, 'From September 11th, 2001 to 9-11,' 285.

43 Holland, 'From September 11th, 2001 to 9-11,' 283.

44 Holland, 'From September 11th, 2001 to 9-11,' 283.

45 Frum, The Right Man, 127, as cited in Holland and Jarvis, “'Night Fell on a Different World”, 194. 
that engaged in a 'double articulation,' simultaneously identifying systemic problems as well as 'a solution to the morbid, underlying condition they were claimed to represent.' 46 The acts of the day were attributed with meaning and, at the same time, a plan of action was articulated. ${ }^{47}$ It is this double articulation that makes 'crisis discourse' a particular discursive construction that, if successful, leads to the final rupturing of dislocated discourses by constructing a threat that demands deep change to existing (discursive) structures. This double articulation is clearly evident in the post-9/11 crisis discourse. ${ }^{48}$ The events of the day were framed as evidence of the new, existential threat international terrorism posed to the U.S. and the international community (the problem) ${ }^{49}$ and the discourse claimed that this threat could only be dealt with by precautionary means (the solution). Below, I work out each articulation in turn; but first, three qualifications are in order.

Firstly, in what follows, particular attention will be paid to the executive discourse on crisis as an indication of how this discourse functioned after September 11, 2001. This is not to say that the executive was the only relevant actor using this discourse, but rather to highlight the privileged position the executive had in setting the terms of the discourse. The specifics of the situation in the early weeks after 9/11 lent itself to a large role for the executive in determining the fate of the discourse dislocated by the events of that day. ${ }^{50}$ The initial silence of the media, ${ }^{51}$ the failure of political opposition to oppose the administration's discourse, ${ }^{52}$ and the administration's successful efforts to delegitimize alternative discourses, ${ }^{53}$ contributed to the Bush administration's ability to 'quickly assert its narrative as the authoritative one among other possibilities. ${ }^{54}$ Secondly, although the following focuses on crisis discourse within the United States, there is evidence that similar mechanisms are also in play elsewhere. As Marieke de Goede concludes regarding Europe, 'European leaders ... may have challenged the war in Iraq, but they are themselves vigorously appropriating and developing important aspects of preemptive security, especially those that make "precautionary logic part of everyday life". ${ }^{55}$ While it is undoubtedly the case that the precise parame-

46 Holland and Jarvis, "'Night Fell on a Different World", 195.

47 Holland, 'From September 11th, 2001 to 9-11,' 283.

48 Holland and Jarvis, "'Night Fell on a Different World”,' 195.

49 This particular framing of the events of 9/11 has of course been challenged on a factual basis (see for more on this Lasse Thomassen, 'De/Reconstructing Terrorism,' review of Philosophy in a Time of Terror, ed. Giovanna Borradori, Theory and Event 7, no. 4 [2004]). I do not argue here that this threat indeed was new, empirically speaking, but rather simply that the discourse framed it as new.

50 See Croft, Culture, Crisis for more on the role of culture as relevant for creating and supporting discourse.

51 Holland, 'From September 11th, 2001 to 9-11,' 281; Richard Jackson, 'Culture, Identity and Hegemony: Continuity and (the Lack of) Change in US Counterterrorism Policy from Bush to Obama,' International Politics 48, nos. 2-3 (2011): 398.

52 Jackson, 'Culture, Identity and Hegemony,' 398.

53 Jackson, 'Culture, Identity and Hegemony,' 398.

54 Jackson, 'Culture, Identity and Hegemony,' 398.

55 De Goede, 'The Politics of Preemption,' 175, citing Richard V. Ericson, Crime in an Insecure World (Cambridge: Polity Press, 2007), 39. 
ters of crisis discourse differ per context, what follows can be seen as a general indication of the arguments the post-9/11 crisis discourse was used to make. Finally, it is important to note that the prevalence of crisis discourse in both official and unofficial speech after $9 / 11^{56}$ does not mean that resistance was completely absent. In fact, sites of resistance certainly existed as Colin Wright has for example identified in relation to the 'Not in Our Name' movement. ${ }^{57}$ Importantly, and as will be discussed in further detail at the end of section 5, such sites of resistance can also be found within the judiciary itself. ${ }^{58}$ Yet, this resistance remained marginal and was quickly sidelined by the crisis discourse that increasingly came to be the accepted story of $9 / 11$.

The first articulation crisis discourse engaged in was the construction of an existential threat. The crisis discourse used by the executive framed the events of 9/11 as an threat not only to the lives of Americans, but also to the continued existence of the values of all of the civilized world. The day after September 11th, President Bush declared 'the deliberate and deadly attacks which were carried out yesterday against our country were more than acts of terror. They were acts of war.' He went on to assert that 'freedom and democracy' were under attack and that this attack was not just on 'our people, but all freedom-loving people everywhere in the world.' According to the President, a 'monumental struggle of good versus evil' had begun. ${ }^{59}$ An opinion article in the New York Times by Secretary of Defense Rumsfeld stated that the President was 'rallying the nation for a war against terrorism's attack on our way of life.' ${ }^{\prime 60}$ Rumsfeld described the opponent in this war as 'the global network of terrorist organizations and their state sponsors, committed to denying free people the opportunity to live as they choose. ${ }^{\prime 61}$ In August 2002, Attorney General Ashcroft decried the attacks as an attempt 'to disrupt and destroy our system of ordered liberty ... The terrorist desires not simply to hurt individual Americans, but to transform America or destroy us if we will not accede to his will. ${ }^{62}$ In addition to being existential, this threat was constructed as un-ending. The Authorization for Use of Military Force granted the president the power to 'use all necessary and appropriate force' to 'prevent any

56 See generally, Holland, 'From September 11th, 2001 to 9-11,' 285; Richard Jackson, Writing the War on Terrorism: Language, Politics and Counter-Terrorism (New Approaches to Conflict Analysis) (Manchester: Manchester University Press, 2005), 155; and Croft, Culture, Crisis.

57 Colin Wright, 'Event or Exception?: Disentangling Badiou from Schmitt, or, Towards a Politics of the Void,' Theory and Event 11, no. 2 (2008).

58 Laura M. Henderson, 'Crisis Discourse: A Catalyst for Legal Change?,' Queen Mary Law Journal 5, no. 1 (2014): 11.

59 George W. Bush, 'Remarks by the President in Photo Opportunity with the National Security Team, The Cabinet Room,' September 12, 2001, available at http://avalon.law.yale.edu/sept11/ president_054.asp, last accessed September 28, 2017.

60 Donald Rumsfeld, 'A New Kind of War,' New York Times, September 27, 2001, available at http:// www.nytimes.com/2001/09/27/opinion/a-new-kind-of-war.html, last accessed September 28, 2017.

61 Rumsfeld, 'A New Kind of War.'

62 John Ashcroft, 'Remarks of Attorney General John Ashcroft: Eighth Circuit Judges Conference,' August 7, 2002, available at https://www.justice.gov/archive/ag/speeches/2002/ 080702eighthcircuitjudgesagremarks.htm, last accessed September 28, 2017. 
future acts of international terrorism against the United States' 63 and in his address to Congress, President Bush emphasized the seemingly unattainable goal of rooting out and defeating 'every terrorist group of global reach. ${ }^{64}$ In 2002, Secretary of Defense Rumsfeld reminded his audience of the persisting threat of terrorism, warning that another attack 'will be attempted. The only question is when and by what technique. It could be months, a year, or several years. But it will happen.' 65

The events of 9/11 were discursively constructed as exceptional and demanding of action, thus preparing the way for the second articulation made by the crisis discourse. The exceptional nature of the era was deemed a 'rupture in time.'66 The problem was presented as one that could not possibly be dealt with by using existing strategies and measures. 9/11 was presented as a fundamental break with previous ways of conceiving of terrorism and security, the 'dividing line in the life of the nation. ${ }^{67}$ As Vice President Cheney remarked,

'... things have changed since last Tuesday [September 11th 2001]. The world shifted in some respects ... We've been subject to targets of terrorist attacks before, especially overseas with our forces and American personnel overseas, but this time because of what happened in New York and what happened in Washington, it's a qualitatively different set of circumstances. ${ }^{68}$

The crisis discourse maintained that the events of $9 / 11$ shattered previous myths, including 'the illusion that the post-Cold War world would be one of extended

63 Public Law 107-40, September 18, 2001, 'Authorization for Use of Military Force,' 115 Stat. 224, available at https://www.gpo.gov/fdsys/pkg/PLAW-107publ40/pdf/PLAW-107publ40.pdf, emphasis added, last accessed September 28, 2017.

64 George W. Bush, 'Address to a Joint Session of Congress and the American People (As Delivered Before Congress),' September 20, 2001, available at http://avalon.law.yale.edu/sept11/president_ 025.asp, last accessed September 28, 2017.

65 Donald Rumsfeld, 'Prepared Testimony of U.S. Secretary of Defense Donald H. Rumsfeld before the House and Senate Armed Services Committees regarding Iraq,' September 18, 2002, available at http://www.sscnet.ucla.edu/polisci/faculty/trachtenberg/useur/rumsfeld180902.html, last accessed September 28, 2017.

66 Richard Jackson, 'The Politics of Threat and Danger: Writing the War on Terrorism,' (paper presented at the British International Studies Association 29th Annual Conference, University of Warwick, December 20-22, 2004), 6, available at http://cadair.aber.ac.uk/dspace/bitstream/ handle/2160/1947/BISA-2004-Paper.pdf?sequence=1\&isAllowed=y, last accessed September 28, 2017.

67 Holland and Jarvis, “'Night Fell on a Different World”,' 194, citing George W. Bush, 'President George W. Bush Signs 9/11 Commission Bill,' November 27, 2001, available at http://www. 911memorial.org/sites/all/files/President\%20Bush\%20Signs\%20911\%20Commission\%20Bill. pdf, last accessed 28 September 2017.

68 Dick Cheney, 'The Vice President Appears on Meet the Press with Tim Russert,' September 16, 2001, available at https://georgewbush-whitehouse.archives.gov/vicepresident/news-speeches/ speeches/vp20010916.html, emphasis added, last accessed 28 September 2017. 
peace. ${ }^{69}$ It succeeded in the 'widespread production [of 9/11] as an interruption of "normal time" 70 and constructed " $9 / 11$ " as a moment of temporal rupture ... Juxtaposed against an imaginary and static pre-" $9 / 11$ " time of individualism, security and peace, this event emerges, simply, as a sudden, unpredictable, bringer of temporal discontinuity. ${ }^{71}$ Importantly, this construction of 9/11 as a time of 'dusk' 'drew upon the lived experience of the events, ${ }^{72}$ contributing to the credibility of the discourse. In this way, the already-dislocated discourse of punishment instead of precaution was pushed toward the point of rupture.

In this discursive reality, a new approach to fighting terrorism was deemed necessary. This is the point at which the executive's crisis discourse engaged in the second of the two articulations discussed above. After a meaning of threat and rupture had been discursively attributed to the events of $9 / 11$, the discourse proceeded to formulate a solution for the threat. After the delegitimation of previous approaches to terrorism, crisis discourse 'took the vital step of (re)constructing the attacks, also, as a moment of dawn. ${ }^{73}$ This discourse posited that a 'genuinely new historical era' ${ }^{74}$ had started, bringing with it a new approach to international terrorism and security. No longer would the 'old, Cold War doctrines' be sufficient. ${ }^{75}$ Rather, 9/11 'demand[s] we think anew and act anew in order to protect our citizens and our values. ${ }^{.76}$ The discourse ushered in 'a new era in which the United States would be focused on fighting and killing terrorists. ${ }^{77}$

As the prevention of terrorism was emphasized over the prosecution of terrorism suspects, the criminal law approach to terrorism receded and an administrative approach took its place. The validity of this new approach relied, discursively, on the weight given to the need to act speedily to prevent new attacks instead of waiting for them to occur and then prosecuting the perpetrators after the attack. In the words of Attorney General Ashcroft '[w]e must prevent first - we must prosecute second'78 and, as President Bush emphasized, the United States 'must

69 Donald Rumsfeld, 'Fiscal 2003 Defense Budget Testimony - House Armed Services Committee (transcript),' February 6, 2002, 4, available at http://www.globalsecurity.org/military/library/ congress/2002_hr/Rumsfeld.pdf, last accessed September 28, 2017.

70 Holland and Jarvis, "'Night Fell on a Different World”,' 190.

71 Lee Jarvis, 'Times of Terror: Writing Temporality into the War on Terror,' Critical Studies on Terrorism 1, no. 2 (2008): 250.

72 Holland and Jarvis, "'Night Fell on a Different World",' 195.

73 Holland and Jarvis, "'Night Fell on a Different World”,' 195.

74 Jarvis, 'Times of Terror,' 247.

75 George W. Bush, 'Remarks by the Vice President to the Heritage Foundation,' Washington DC, May 1, 2003, available at https://georgewbush-whitehouse.archives.gov/news/releases/2003/05/ 20030501-9.html, last accessed September 28, 2017.

76 John Ashcroft, 'Statement of John Ashcroft Attorney General of the United States before the Committee on the Judiciary United States Senate concerning Oversight of the Department of Justice,' July 25, 2002, available at https://www.justice.gov/archive/ag/testimony/2002/ 072502agtestimony.htm, last accessed September 28, 2017.

77 Holland and Jarvis, “'Night Fell on a Different World”,' 195.

78 John Ashcroft, 'Testimony before the House Committee on the Judiciary,' September 24, 2001, available at https://www.justice.gov/archive/ag/testimony/2001/agcrisisremarks9_24.htm, last accessed September 28, 2017. 
look at security in a new way, because our country is a battlefield in the first war of the 21st century. ${ }^{79}$ The administrative approach posited a larger prerogative for the executive in dealing with terrorism than the criminal law approach did: under this new approach, the executive's powers could be used to deal militarily with the terrorist threat, to impose measures designed to reduce potential risk posed by individuals, groups or in particular situations. Moreover, the executive traditionally enjoys more discretion when acting within the purview of administrative law than within criminal law. By claiming that the aim was not to punish perspective terrorists, but merely contain the risk they posed with administrative measures, the government expected more legal room to maneuver.

This approach, based on prevention, was discursively used to color the 'new era' of the post-9/11 world and the approach this new era demands. The unprecedented uncertainty of the existential threat terrorism supposedly posed was used within this discourse to justify the exceptional and unprecedented response to this threat and the necessity for prevention over prosecution. ${ }^{80}$ The success of framing $9 / 11$ as such a fundamental break with the past, meant that the already dislocated security narratives became ruptured. 'The sense of rupture and crisis' engendered by the $9 / 11$ attacks 'opened the necessary discursive space' for the articulation of an alternative approach to terrorism. ${ }^{81}$ The crisis discourse that emerged post-9/11 was ubiquitous in executive speech, the media, think tanks, ${ }^{82}$ and quickly took hold among the U.S. public, as shown by the interviews Holland analyzed. Holland concluded, 'if on September 11th the events of the day were relatively meaning-less, in the days that followed, the meaning of 9-11 was increasingly homogenous and hegemonic. ${ }^{\prime 83}$ According to Richard Jackson, who examined over 300 pages of executive speeches, there were 'virtually no instances of deviation from the primary narratives; the words used were almost identical, the grammatical structures the same and the meanings remained constant. ${ }^{\text {' } 4}$ Jackson explains how such strong coherence reinforced the believability of the narrative and increased the influence among its audience. ${ }^{85}$ This did not mean that all dissent was absent but that overall 'crisis' was becoming the prevailing lens through which to view the events of that Tuesday morning in 2001. Importantly, it was this crisis discourse that provided the conditions of possibility for the judiciary's participation in the post-9/11 precautionary turn. As the next section shows, the crisis discourse that emerged in political and cultural spaces after 9/11 did not stop at the door to the courtroom and was exhibited in legal discourse as well. dent's Address Yesterday Evening on the Future of Iraq,' February 27, 2003, available at https:// www.theguardian.com/world/2003/feb/27/usa.iraq2, last accessed September 28, 2017.

80 Jarvis, 'Times of Terror,' 251.

81 Jackson, 'Culture, Identity and Hegemony,' 397.

82 Croft, Culture, Crisis.

83 Holland, 'From September 11th, 2001 to 9-11,' 285.

84 Jackson, Writing the War on Terrorism, 154.

85 Jackson, Writing the War on Terrorism, 155. 


\section{Crisis in the courtroom}

This section will consider crisis discourse as it appears in a number of terrorism cases. I propose another look at cases where the shift toward precautionary logic in the judiciary is particularly evident, in light of the dislocation after 9/11 and the rupturing effects of crisis discourse described in the previous sections. The cases I will deal with below, Hamdi, Suresh, and Barot, are cases used by Hafetz, Gelev and De Goede \& De Graaf, respectively, to show that the precautionary shift has taken place in the judiciary. My analysis of these cases takes our understanding of this shift a step further as I show how these cases also provide insight into how this logic entered into judicial discourse by highlighting the role of crisis discourse in articulating a threat of terrorism and positing need for exceptional solutions.

After the events of 9/11 exposed the inability of previous discourses to fully describe all social reality (thus uncovering the inevitable lack or gap between discourse and human experience), the discourse of a purely criminal law approach to terrorism was dislocated. The crisis discourse that subsequently emerged in the political sphere worked to finally rupture this weakened discourse and replace it with one of prevention. In this section, we will see that crisis discourse not only ruptured the discourse of a criminal law approach to terrorism in the political sphere, but also had this effect in the legal judgments inspected here. The double articulation crisis discourse engaged in - the articulation of the existential threat of terrorism and the articulation of preventive action as the only solution to this threat - ruptured the already-dislocated criminal law discourse by providing the legitimation and the perceived necessity of the precautionary approach. In this way, in the courtroom as well as in the political debate, crisis discourse ruptured the previous discourse of criminal law, subsequently piecing together a new discourse based on the existential threat of terrorism and the necessity of preventive measures.

The U.S. Supreme Court's decision in the Hamdi case is exemplary of how the crisis discourse used by the executive created the conditions of possibility for the precautionary turn in the law. In this case, the Court considered whether Mr. Hamdi's preventive, administrative detention had been legally authorized and whether it complied with the constitutional right to due process. The U.S. armed forces detained Mr. Hamdi after determining he was an enemy combatant in Afghanistan. The Court in Hamdi began its ruling on the case with a candid admission of the 'difficult time in our Nation's history' in which the case took place. ${ }^{86}$ The following paragraph spelled out the context in more detail, referring to the 'acts of treacherous violence' committed by the perpetrators of the 9/11 attacks. ${ }^{87}$ The problem discursively constructed by the Court specifically related to the 'armed conflict' ${ }^{88}$ the U.S. was engaged in, which was connected to a threat 
from persons closely related to those who planned the attacks of $9 / 11$, and a concern with preventing such individuals from engaging in the international conflict that had been ongoing since those attacks. ${ }^{89}$ The Court found the preventive, administrative detention of such individuals to be 'clearly and unmistakably' an instance of 'necessary and appropriate force. 90 The threat posed by these individuals was found to make it necessary to preventively detain these individuals; not as punishment but as prevention of future risks. It is interesting to note that while the Court was deciding on what procedural protections apply to these detainees, it acknowledged the importance of protection of the right to liberty but nevertheless held that in this context of 'international conflict' the 'full protections that accompany challenges to detentions in other settings' need not apply. ${ }^{91}$ The Court authorized the 'tailoring' of legal proceedings 'to alleviate their uncommon potential to burden the Executive at a time of ongoing military conflict. ${ }^{\text {'92 }}$ In this way, individuals who were preventively detained fell outside a criminal law detention regime and did not receive the protections (criminal) detainees received. Instead, an ad-hoc, administrative law regime was created and, by adopting this approach, the Court sanctioned a preventive mode of counterterrorism. The government was found able to detain an individual based on the risk of future damage and before that individual had committed any crime.

In Suresh, at issue was whether the Canadian Charter of Rights and Freedoms would allow the deportation of a refugee who posed a threat to Canada to a country where the refugee faced a risk of torture. The Supreme Court of Canada decided that there could be 'exceptional' cases in which such deportation could be justified. ${ }^{93}$ As Gelev pointed out, 'the judiciary showed a real willingness to assist the executive in its fight against terrorism through precautionary justice. ${ }^{94}$ In Suresh, the judges employed crisis discourse to articulate a problem and solution that matched the problem and solution formulated in the broader political use of crisis discourse. First, the judiciary pointed to the existence of the threat posed by terrorism, acknowledging the presence of 'the manifest evil of terrorism and the random and arbitrary taking of innocent lives, rippling out in an ever-widening spiral of loss and fear, ${ }^{95}$ which was, according to the Supreme Court of Canada, 'a worldwide phenomenon. '96 According to the Court, 'after the year 2001' the old approach to this threat (assuming that terrorism in one country does not affect other countries) was 'no longer valid. ${ }^{97}$ The Court continued to suggest a solution to this problem: 'preventive or precautionary state action may be justified; not only an immediate threat but also possible future risks must be considered. ${ }^{98}$ It is

89 Hamdi v. Rumsfeld, 9, 23.

90 Hamdi v. Rumsfeld, 12.

91 Hamdi v. Rumsfeld, 28.

92 Hamdiv. Rumsfeld, 27.

93 Suresh v. Canada, 2002 SCC 1, para. 129.

94 Gelev, 'Checks and Balances,' 2251.

95 Suresh v. Canada, para. 3.

96 Suresh v. Canada, para. 88.

97 Suresh v. Canada, para. 87.

98 Suresh v. Canada, para. 88. 
this articulation of problem and solution, in line with crisis discourse as described above, that provided the justification for the Court's decision to allow the possibility to depart from normal rules in order to prevent terrorism.

Crisis discourse was also used by the UK Court of Appeals in Barot. In this case, the Court dealt with Mr. Barot's conviction of conspiracy to murder, related to Mr. Barot's preparations of a terrorist attack. The Court had to decide whether imposing a sentence of indeterminate length, with a minimum of 40 years imprisonment but no maximum, was excessive. In this case as well, the Court used crisis discourse. The Court articulated the problem certain terrorists pose as serious and potentially unending:

'A terrorist who is in the grip of idealistic extremism to the extent that, over a prolonged period, he has been plotting to commit murder of innocent citizens is likely to pose a serious risk for an indefinite period if he is not confined.' 99

More generally, the Court also discussed the overall threat posed by terrorism as 'rampant in the world' and expressed concern about 'many other terrorist plots,' referring to the 'carnage' terrorists are bent on committing. ${ }^{100}$ The Court further noted that the House of Lords had recently decided a case in which it found 'the terrorist threat represented "a pubic emergency threatening the life of the nation".'101

Similar to Suresh, the Court of Appeal in Barot qualified this problem as 'different in degree ${ }^{\text {'102 }}$ to that posed by earlier episodes of terrorism in the United Kingdom. The Court found that 'terrorist offences today are capable of being more serious [than those dealt with previously] ... This case demonstrates the search by the terrorists for a means of causing death on an even greater scale than results from the destruction of a passenger plane and the events of 9/11 show that this can be achieved. ${ }^{103}$ These considerations led the Court to conclude that previous guidelines for sentencing must be reconsidered ${ }^{104}$ and held that an indeterminate sentence can be an appropriate sentence. ${ }^{105}$ We see that, here too, the Court used crisis discourse to articulate a threat of terrorist attacks that demanded exceptional, preventive measures, thus making the precautionary turn.

These three cases provide an illustration of crisis discourse at work in the judiciary's legal discourse. I have attempted to build on previous analyses of these cases, which highlighted the presence of precautionary logic in the judiciary's discourse. What my analysis adds is a focus on how crisis discourse and its particular

99 Regina v. Barot [2007] EWCA Crim 1119, para. 37.

100 Regina v. Barot, para. 42.

101 Regina v. Barot, para. 55.

102 Regina v. Barot, para. 54.

103 Regina v. Barot, para. 55.

104 Regina v. Barot, para. 55.

105 Regina v. Barot, para. 37. 
articulations of problem and solution provide the conditions of possibility for the judiciary's adoption of the post- $9 / 11$ precautionary logic of counterterrorism in its judgments. By showing crisis discourse at work in these cases, an indication is given of how crisis discourse is able to construct legal problems and, subsequently, provide legal solutions. At the same time, this analysis suggests that a better understanding within the judiciary of the mechanisms of crisis discourse and the assumptions it relies on would have positioned the judiciary to interrogate these assumptions more rigorously. The majority decisions in these cases show evidence of judges adopting crisis discourse and building upon its assumptions without an extensive examination or defense of their validity.

It is important to note that the adoption of crisis discourse by the judiciary in these cases, and the precautionary shift this discourse was used to justify, were not inevitable. They were the product of 'decisive interventions' ${ }^{\prime} 106$ by the executive and other actors at a time when previous discourses were unsettled and vulnerable. Even after the emergence of the crisis discourse, the possibility of closing the dislocation and preventing a rupture in the previous discourses on terrorism was still a possibility. This is evidenced particularly convincingly in the court of first instance's ruling on Hamdi, in which the presiding Judge Doumar resisted the framing of the crisis by the government, even in the face of orders from the Appellate Court to show more deference to the executive. Judge Doumar challenged the government's claim that this case was being heard at a time of war, ${ }^{107}$ pointed to the threat involved in the government's undermining of constitutional protections ${ }^{108}$ and re-framed the appeal to the exceptional nature of the case at hand to relate to the government's extraordinary detention of Mr. Hamdi. ${ }^{109}$ In the end, however, Judge Doumar's refusal to adhere to the crisis discourse was met with the threat of a clash between the executive and the judiciary - with the executive refusing to comply with Judge Doumar's order to provide Mr. Hamdi access to an attorney. Judge Doumar accepted that since he was not prepared to 'throw [...] the Secretary of Defense in jail,',110 he had to allow the government to proceed with appeal instead of enforcing his order. On appeal, the crisis discourse and the precautionary approach to counterterrorism it discursively justified prevailed. While this is just one example of how resistance to crisis discourse and the shift toward precautionary measures was both possible and, at the same time, met with powerful opposition by both the executive and the larger judicial organi-

106 Hay, 'Crisis and the Structural Transformation,' 323.

107 Hamdi v. Rumsfeld, United States District Court for the Eastern District of Virginia, Transcript of Proceedings before the Honorable R. G. Doumar (29 May 2002) Joint Appendix I, 2004 WL 1120871 (U.S.), 34.

108 Hamdi v. Rumsfeld, United States District Court for the Eastern District of Virginia, Order (16 August 2002) Joint Appendix II, 2004 WL 1123351 (U.S.), 9.

109 Hamdi v. Rumsfeld, United States District Court for the Eastern District of Virginia, Transcript of Proceedings before the Honorable R. G. Doumar (13 August 2002) Joint Appendix I, 2004 WL 1120871 (U.S.), 85.

110 Hamdi v. Rumsfeld, United States District Court for the Eastern District of Virginia, Transcript of Telephonic Conference before the Honorable Robert G. Doumar (20 August 2002) Joint Appendix II, 2004 WL 1123351 (U.S.), 13-17. 
zation, it indicates that even the powerfully-hegemonic crisis discourse nevertheless left some room for challenge.

\section{Conclusion}

The emergence of a crisis discourse after the initial dislocation of 9/11 made the precautionary turn in legal discourse possible. This crisis discourse engaged in a double articulation: first, this discourse constructed 9/11 as an existential threat and definitive break with the past that called for new ways of dealing with terrorism. This construction led to the decisive rupture of the dislocated, and thus weakened, pre-9/11 discourses on security. Secondly, this crisis discourse articulated the necessity and appropriateness of preventive approaches to counterterrorism in this 'new era' of (in)security. Without a post-9/11 crisis discourse, and without the specific double articulation it employed, the shift from criminal-law logic to the precautionary logic that emerged, would have been unthinkable. ${ }^{111}$

The mainly descriptive approach I take in this article provides a necessary foundation for exploring the normative implications of crisis discourse. By setting out a theoretical and descriptive account of how crisis discourse is able to call particular change into being, this article provides a starting point for further research. In order for one to examine the way crisis discourse might affect normative principles, one cannot ignore the specific ways in which and the specific context within which crisis discourse is used. Moreover, while this article highlighted crisis discourse's role in facilitating the shift toward a precautionary approach to terrorism, showing how crisis discourse served to discursively justify this shift, it is important to note that crisis discourse's emergence and success was not inevitable. While discourse might create meaning and determine our perception of reality, the success of this discourse depends on its use by specific actors at specific points in time. The insight this article gives into crisis discourse's contribution to shifts in legal discourse challenges those engaged in legal discourse to be conscious of their role in either using or contesting crisis discourse in the struggle over legal meaning.

111 See for more on how discourse fashions the limits of the (un)acceptable, Stuart Hall 'The Work of Representation,' in Representation: Cultural Representations and Signifying Practices, ed. Stuart Hall (London: Sage, 1997), 44: 'Just as discourse "rules in" certain ways of talking about a topic, defining an acceptable and intelligible way to talk, write, or conduct oneself, so also, by definition, it "rules out", limits and restricts other ways of talking, of conducting ourselves in relation to the topic or constructing knowledge about it.' 